\title{
An Islamic Perspective on Peaceful Coexistence
}

\author{
Kabuye Uthman Sulaiman
}

ABSTRACT

According to Abrahamic religions, namely Judaism, Christianity and Islam, human beings exist on the earth for a common purpose, and they have patrilineally and matrilineally descended from a single couple, namely Adam and Hawa (Eve). The Qur'an unambiguously mentions: "O mankind! reverence your Guardian-Lord, who created you from a single person, created, of like nature, His mate, and from them twain scattered (like seeds) countless men and women; reverence Allah, through whom ye demand your mutual (rights), and (reverence) the wombs (That bore you): for Allah ever watches over you."1 Thus, it is incumbent upon human beings to live together in peace rather than constant hostility to fulfil the purpose of their existence on the earth. This paper endeavours to contribute to the understanding of the concept of 'peaceful coexistence' from the Islamic perspective. It specifically answers the following research questions: What is peaceful coexistence? What is necessary for peaceful coexistence? What are the fundamental principles that we must adhere to in order to coexist peacefully? The paper is structured into eight sections, beginning with introduction on the concept of 'peace' in Islam. The second section focuses on the main objectives of Islam. The third section is on the meaning of peaceful coexistence. The fourth and fifth sections are on the need for peaceful coexistence, and the necessary requirements and tools for peaceful coexistence respectively. The sixth section is on categorization of peaceful coexistence into: peaceful coexistence in marriage, peaceful coexistence of mankind, peaceful coexistence of the members of the Muslim ummah and peaceful coexistence of mankind and the environment. The seventh section is a summary of the Islamic principles of peaceful coexistence. The final section sums up the main conclusions drawn from this study. The translation of the ayat (verses) of the Qur'an related to this study is extracted from the work of Abdullah Yusuf Ali, The Holy Qur'an: Text and Translation unless stated otherwise. At the end of this paper, it is hoped that the readers will: first, appreciate the message of Islam as a universal religion and the need for mutual care, mutual respect, and mutual cooperation; and second, explore the methodology of the Qur'an and the Prophet Muhammad (peace and blessings be upon him) in managing human diversity. It is also hoped that this study will lead to a better understanding of peaceful coexistence as an integral part of Islam and one of the characteristics of the Muslim ummah. The findings of this study highlight the role of Islam in promoting peace and security. The study reveals that peaceful coexistence is a key factor in the success of human beings and it requires nurturing love, respect, care, and salam (a greeting of peace) in one's relationship with others.

Keywords: Muslim ummah, mutual cooperation, mutual respect, peaceful coexistence, salam, solidarity, wasatiyyah.

\section{INTRODUCTION}

Islam is undeniably the greatest blessing Allah has bestowed upon mankind as mentioned below:

"This day have I perfected your religion for you, completed My favour upon you, and have chosen for you Islam as your religion." 2

"Allah has bestowed countless blessings upon us. He has endowed us with the gifts of sight and hearing, the intellect, health, wealth, and family. He has even subjected everything
Published Online: October 27, 2021

ISSN: $2736-5514$

DOI : $10.24018 /$ theology.2021.1.5.50

K. U. Sulaiman

Department of Fundamental and InterDisciplinary Studies, Kulliyyah of Islamic Revealed Knowledge and Human Sciences, International Islamic University Malaysia, Malaysia.

(e-mail: kabuye@iium.edu.my) in the universe for us: the sun, the moon, the heavens and the earth, and many countless things...However, all these blessings will cease to exist when our short worldly life comes to an end. The only blessing that is bound to bring about happiness and tranquillity in this life and eternal bliss in the hereafter is the blessing of being a Muslim" [1].

Etymologically, the term 'Islam' stems from the root salm or salam, meaning 'peace', 'security' and 'submission'. Hence, attainment of peace and security, and promoting peace and security in the world constitutes part of the 
objectives of Islam. This objective is only achieved through complete submission to Allah, which is strict adherence to al-Shari'ah, or the path to Allah. This path, which is also known as al-Sirat al-Mustaqim, the Straight Path, is what the Messengers (peace and blessings be upon them) were sent with and for which Allah revealed the Books. It is the only path leading mankind to Dar al-Salam, the abode of peace (Jannah). Allah says (interpretation of the meaning):

"But Allah doth call to the Home of Peace: He doth guide whom He pleaseth to a way that is straight."3

"Verily, this is My way, leading straight: follow it: follow not (other) paths: they will scatter you about from His (great) path: thus, doth $\mathrm{He}$ command you. that ye may be righteous."

The phrase "Verily, this is My way, leading straight" is a reference to Islam and its legal system or al-Shari 'ah. Hence, Islam is the only religion that can unite mankind and lead it to al-Falah, success and prosperity in this life and in the Hereafter life. Allah says (interpretation of the meaning):

"Who can be better in religion than one who submits his whole self to Allah, does good, and follows the way of Abraham the true in Faith? For Allah did take Abraham for a friend." 5

"The same religion has He established for you as that which He enjoined on Noah - the which We have sent by inspiration to thee - and that which We enjoined on Abraham, Moses, and Jesus: Namely, that ye should remain steadfast in religion, and make no divisions therein: to those who worship other things than Allah, hard is the (way) to which thou callest them. Allah chooses to Himself those whom $\mathrm{He}$ pleases, and guides to Himself those who turn (to Him). $"$

Here it worth noting that peace is a concept found in all religions and philosophies. However, it is perceived differently. It is also worth noting that attainment of peace is required at two levels: first, at the individual level, which is to be at peace with oneself, and second, at societal level, which is to be at peace with one's fellow human beings. This is also termed as 'peaceful coexistence'. Thus, salam can be well described as an Islamic concept defining the relationship between Muslims and Muslims, and Muslims and nonMuslims. It is one of the ways to develop a loving, caring, and peaceful relationship with one's fellow human beings. Allah says (interpretation of the meaning):

"And the servants of (Allah) Most Gracious are those who walk on the earth in humility, and when the ignorant address them, they say, Salam "Peace!"7

From this verse it is understood that promoting peaceful coexistence (living with others in peace and harmony rather than in hostility) is one of the noble qualities of 'ibad alRahman (servants of the Most Merciful, i.e., Allah). When abused by the ignorant, they never lose control of themselves. Instead of responding in a similar way, they forgive and reconcile with them (the ignorant). This is termed as islah. While salam means "peace" islah means to live peacefully with others, including the ones who wrong us, to put things in a better position, to reconcile people with one another, to make peace, etc. Allah says (interpretation of the meaning):
"The Believers are but a single Brotherhood: So, make peace and reconciliation between your two (contending) brothers; and fear Allah, that ye may receive Mercy."

"In most of their secret talks there is no good: But if one exhorts to a deed of charity or justice or conciliation between men, (Secrecy is permissible): To him who does this, seeking the good pleasure of Allah, We, shall soon give a reward of the highest (value)." $"$

Islah or reconciliation is one of the best means of attaining nearness to Allah. It is a noble act and character that Allah and His Messenger (peace and blessings be upon him) love. Islam considers reconciliation between disputants as a method of conflict resolution and a method through which unification of the members of society should be realized.

In a nutshell, 'ibad al-Rahman have a healthy relationship with all mankind which is only possible with far-sightedness and intellectual maturity or "the adult stage of intellectual development, in which the individual typically has a high level of good judgment, often combined with wisdom" [2].

Furthermore, it is worth noting that the journey to peaceful coexistence begins with the attainment of peace with oneself, which is termed as 'inner peace'. What is inner peace? Why is it important, and how is it achieved? These are fundamental questions of tasawwuf (Islamic spirituality). Inner peace is defined, among others, as follows: being mentally and spiritually at peace; freeing one's mind from worry and negative thoughts; a state in which the mind is quiet and serene [3]; and, having the ability to connect to Allah, Al-Salam (The Source of peace).

Additionally, inner peace can be defined as a state of being that is attainable through: belief in Allah and complete submission to Him, contentment with Allah's decree, absolute trust, and confidence in God (Allah) [4], detaching the self from the material world [4], giving life and events a tawhid-centric worldview [4], and purification of the heart from diseases such as arrogance, envy, hatred, etc. These are all examples of not being at peace with oneself, hence not being at peace with others. 'Peace with oneself' and 'inner peace' are used interchangeably. The Islamic concepts for 'inner peace' or 'peace with oneself' are: ridha (contentment), sakinah (serenity) and itmi'nan (tranquility).

In its widest and most inclusive sense, the term Islam refers to 'submission to Allah'. This is necessary because Allah is, among others, Al-Salam, meaning the One Who grants peace, safety, security, contentment, serenity, comfort, tranquility, and calmness.

The standard greeting for Muslims whenever and wherever they meet is al-Salam 'alaykum, meaning 'peace be upon you', 'may you be peaceful, safe and secure' or 'may Allah grant you peace, safety and security'. Thus, al-Salam 'alaykum it is not simply a greeting, but a $d o$ 'a, an invocation, a prayer for peace, comfort, calmness and security, and a promise to the receivers of this noble Islamic greeting that 'they are secured from harm, both physical and emotional'. It is a mutual exchange of promises of peace, security and harmony. It was narrated from Abu Hurayrah (may Allah be pleased with him) that: The Messenger of

${ }_{3}^{3}$ Qur'an, 10:25.
${ }^{4}$ Qur'an, 6:153.
${ }^{5}$ Qur'an, 4:125.
${ }^{6}$ Qur'an, 42:13. 
Allah (peace and blessings be upon him) said: "The Muslim is the one from whose tongue and hand the people are safe, and the believer is the one from whom the people's lives and wealth are safe" [5]. In a different Hadith, narrated 'Abdullah bin 'Amr that: The Prophet (peace and blessings be upon him) said: "A Muslim is the one who avoids harming Muslims with his tongue and hands. And a Muhajir (emigrant) is the one who gives up (abandons) all what Allah has forbidden" [6].

One of the objectives of giving and responding to al-Salam 'alaykum is to increase love and compassion among believers. Abu Hurayrah (may Allah be pleased with him) reported: The Messenger of Allah (peace and blessings be upon him) said: "You will not enter Paradise until you have faith and you will not have faith until you love each other. Shall I show you something that, if you did, you would love each other? Spread al-Salam (peace) between yourselves" [7].

We are currently living in a world where inner peace and sustained happiness are hard to achieve due to perpetual wars, terrorism, crimes, diseases, environmental disasters, and social, economic and political conflicts. Hence, the question of how to achieve inner peace and sustained happiness becomes very fundamental.

\section{The Main ObJectives of ISLAM}

Human diversity in the form of race, ethnicity, gender, language, socioeconomic status, mental and physical capabilities, and religious affiliation is an integral feature of mankind and therefore, a reality that should not be ignored. Allah says (interpretation of the meaning):

"O mankind! We created you from a single (pair) of a male and a female, and made you into nations and tribes, that ye may know each other (not that ye may despise (each other). Verily the most honoured of you in the sight of Allah is (he who is) the most righteous of you. And Allah has full knowledge and is well acquainted (with all things)."10

Therefore, Islam came to unite people and not to divide them. It teaches that all human beings have patrilineally and matrilineally descended from a single couple, namely Adam and Hawa (Eve) (Qur'an, 4:1). Hence, they should live together peacefully as brothers to each other and work collectively to achieve al-Falah (success or wellbeing in this earthly life and the eternal life in the Hereafter) rather than fight one another, hate each other, quarrel with one another, discriminate against another, etc. The following are some of the main objectives of Islam:

First, to establish a united, inclusive, integrated, and consolidated Muslim community, that is, a community in which people of different races and ethnicities live in mutual tolerance because of common beliefs and rituals. Allah says (interpretation of the meaning): "And verily this Brotherhood of yours is a single Brotherhood, and I am your Lord and Cherisher: therefore, fear Me (and no other)." 11 The Prophet (peace and blessings be upon him) likened the relation of the members of the Muslim community with each other to: first, the body, when a part of it is afflicted the whole of it is afflicted with fever and restlessness; second, the bricks of a wall, each is strengthened by the other; and third, the head, when any part of the body is afflicted, it is afflicted with pain and restlessness. Montgomery Watt regards integration or unity in diversity as one of the unique characteristics of Islam: "One of the distinctive marks of Islam, compared with other great religions, is the variety of people and races who have embraced it, and among whom there has grown a strong feeling of brotherhood and a measure of harmony Perhaps a study of the achievements of Islam may throw some light on how the integration of world society is likely to come about, and may even suggest ways in which man may consciously contribute to this process" [8].

Second, to purify human souls from the spiritual diseases of the heart, such as hatred, malice and the intention to harm others: "Truly he succeeds that purifies it, and he fails that corrupts it!"12; "The Day whereon neither wealth nor sons will avail, but only he (will prosper) that brings to Allah a sound heart."13 The Islamic term for purification of human souls is tazkiyat al-Nafs. Narrated Anas bin Malik (May Allah be pleased with him): The Prophet (peace and blessings be upon him) said: "Do not hate each other, do not envy each other, do not turn away from each other, but rather be servants of Allah as brothers. It is not lawful for a Muslim to boycott his brother for more than three days" [7].

Third, to build peaceful and harmonious interpersonal relationships and also human relationship with other living beings and the environment: "And remember Moses prayed for water for his people; We said: "Strike the rock with thy staff." Then gushed forth therefrom twelve springs. Each group knew its own place for water. So eat and drink of the sustenance provided by Allah, and do no evil nor mischief on the (face of the) earth"14; "But seek, with the (wealth) which Allah has bestowed on thee, the Home of the Hereafter, nor forget thy portion in this world: but do thou good, as Allah has been good to thee, and seek not (occasions for) mischief in the land: for Allah loves not those who do mischief." 15

Fourth, to liberate people from oppression, release them from bondage of their desires and provide them with the means for their happiness: "By the Soul, and the proportion and order given to it; and its enlightenment as to its wrong and its right. Truly he succeeds that purifies it, and he fails that corrupts it!"16

Fifth, to provide mankind with light that leads from the darkness to the path of peace and salvation: "Wherewith Allah guided all who seek His good pleasure to ways of peace and safety, and leadeth them out of darkness, by His will, unto the light, guideth them to a path that is straight." 17

\section{MeAning of Peaceful CoeXistence}

Peaceful coexistence is a concept of international relations and one of the fundamental principles of international law: "The principle of peaceful coexistence is a universally

\footnotetext{
${ }^{10}$ Qur'an, 49:13.

${ }^{11}$ Qur'an, 23:52.

${ }^{12}$ Qur'an, 91:9-10.

${ }^{13}$ Qur'an, 26:88-89.
}

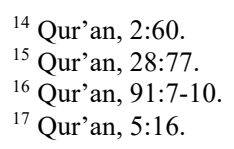


recognized principle of modern international law; ... whereas international law of the past was a law of war and peace, it has today become a law of peace and peaceful coexistence." This is a 1962 declaration of "The Committee on Peaceful Coexistence of the Soviet Association of International Law" [9]. From this declaration it is understood that 'international law' and 'the principle of peaceful coexistence' are now used interchangeably. What is peaceful coexistence? Peaceful coexistence is precisely defined as.

"Recognition of the right of the other group to exist peacefully with its differences, acceptance of the other group as a legitimate and an equal partner with whom disagreements have to be resolved in nonviolent ways" [10].

having "a relationship between persons or groups in which none of the parties is trying to destroy the other" [11].

"a state in which two or more groups are living together while respecting their differences and resolving their conflicts nonviolently" [12].

In view of these definitions, peaceful coexistence implies that although conflict and disagreement may still be intact, the involved groups have decided to abandon violent ways of confrontation and choose to live in peace, using peaceful means to achieve their goals. This means:

a) No group harms or threatens the other group(s) without a justified reason.

b) No group seeks to advance its interests at the expense of others.

\section{The NeEd for Peaceful Coexistence}

Nothing in the universe is without a purpose. The purpose of creating human beings in different tribes and races is to know each other, connect to each other, integrate with each other, learn from each other, help each other become successful in life, peacefully coexist with one another, and finally, yet importantly, to show the Power and Might (Greatness) of Allah rather than the greatness or superiority of one race, nation, color, or language over another and to bear witness that none deserves worship but Him, etc. Allah says (interpretation of the meaning):

"O mankind! We created you from a single (pair) of a male and a female, and made you into nations and tribes, that ye may know each other (not that ye may despise (each other). Verily the most honored of you in the sight of Allah is (he who is) the most righteous of you. And Allah has full knowledge and is well acquainted (with all things)."18

"And among His Signs is the creation of the heavens and the earth, and the variations in your languages and your colors: verily in that are Signs for those who know."19

It should be noted that peaceful coexistence is needed in all ages in order to earn the pleasure of Allah. According to the following Qur'anic verse, solidarity is fundamental in bringing about victory. Allah says (interpretation of the meaning): "Truly Allah loves those who fight in His Cause in battle array, as if they were a solid cemented structure."20 This verse highlights the importance of unity and solidarity in facing the enemy and the challenges of life. It is understood from this verse that in order to earn Allah's pleasure and also to attain victory we have to unite as one strong, unified structure rather than fight as disunited races, ethnicities or nation states.

The following phrases summarize the spirit of peaceful coexistence of human beings:

"We must unite, not to be together, but to do something together" - Juan Donoso Cortés.

"Our task must be to free ourselves from this prison by widening our circle of compassion to embrace all living beings and all of nature" - Albert Einstein [13].

"Only the unity of all can bring the well-being of all" Robert Muller [13].

"You may call for peace as loudly as you wish, but where there is no brotherhood there can in the end be no peace" Max Lerner [13].

"We may have all come on different ships, but we're in the same boat now" - Martin Luther King, Jr. [13].

"Either men will learn to live like brothers, or they will die like beasts" - Max Lerner [13].

"United we stand, divided we fall" - Aesop (620 -560 BC) [13].

"If we wish to create a lasting peace we must begin with the children" - Mahatma Gandhi" [13].

"At the center of non-violence stands the principle of love" - Martin Luther King, Jr. [13].

"We come into the world like brother and brother, and now let's go hand in hand, not one before another." - William Shakespeare.

"A person must make peace with oneself before they will find peace with the world" - Kilroy J. Oldster [14].

"If we are to live together in peace, we must come to know each other better" - Lyndon B Johnson [13].

"Peace cannot be kept by force. It can only be achieved by understanding" - Albert Einstein [13].

"First there must be order and harmony within your own mind" - Confucius.

\section{THE NECESSARY REQUIREMENTS AND TOOLS FOR PEACEFUl COEXISTENCE}

The aim of this section is to describe the following tools and requirements for peaceful coexistence:

1) Creation of awareness.

2) Education.

3) Viewing others as having the same right to exist and live-in peace.

4) Acknowledgement of the differences among people. Their differences may be "in the realm of goals, values, ideology, religion, race, nationality, ethnicity, culture, and other domains" [10].

5) Implementation of core values.

6) Communication skills.

7) Managing conflicts in an amicable manner.

\section{A. Creation of Awareness}

The first step towards peaceful coexistence is awareness. We must first be aware that Allah created all human beings from Adam and Hawa (Eve) and made them different in

\footnotetext{
${ }^{18}$ Qur'an, 49:13.

${ }^{19}$ Qur'an, 30:22.
}

${ }^{20}$ Qur'an, 61:4. 
gender, race, and ethnicity but with a common goal, that is, attainment of His pleasure by acting according to His commands.

The government plays an important role in creating awareness. There are several programmes, policies and activities that can be invented by the government to ensure that people of different races, ethnicities and religions coexist peacefully and harmoniously. Among them is 'education for coexistence'. It is "the process through which society members are supposed to acquire the beliefs, attitudes, and behaviors that are in line with the ideas of coexistence" [10].

\section{B. Education}

The second step towards peaceful coexistence is education: "We must obtain the necessary information and knowledge about those who are different" [15]. His Majesty King Hamad bin Isa Al-Khalifa, king of The Kingdom of Bahrain, described ignorance as "the enemy of peace" and he considered it our "duty to learn, to share, and to live together, by the tenets of faith in the spirit of mutual respect and love" [16]. Jeff Kottler exhorted us to "have the courage to enter into the world of those (we) are trying to understand by learning their unique cultures, family histories, languages, customs, values, and priorities" [15].

Awareness is often achieved through education. Therefore, one of the goals of education is to acquaint people with facts about racial and ethnic diversity and to promote peaceful coexistence. Bar-Tal has adequately and precisely described what education for coexistence involves as follows:

First, "transmission of knowledge, creation of experiences, and development of skills which can help to develop the psychological repertoire that accepts, recognizes, respects, legitimizes, humanizes, and personalizes the rival or discriminated group." Among the things needed to achieve this objective are the following:

(1) creation and implementation of educational policy which supports coexistence,

(2) written textbooks (on peaceful coexistence),

(3) training of teachers,

(4) construction of experiential programs,

(5) creation of proper learning climates [10].

Second, "changing the socio-psychological repertoire of society at large. The assumption is that there is a need for political, social, and cultural change in the whole of society since education for coexistence cannot succeed if it is not activated on a broad societal scale. Schools can play an important role in bringing about such change, but they constitute only one agent, and a major societal change requires the participation of political, societal, and cultural institutions, mass communication, leadership, and elites" [10].

Additionally, he has described the following features of education for coexistence:

(1) It consists of formal and planned processes (for example in schools) as well as of informal processes (for example via mass media)

(2) it involves participation of the society's political, social, cultural, religious, and educational leaders on the national and community levels to disseminate the ideas of coexistence

(3) it takes place in all the institutions of the societypolitical, social, cultural, educational, economic, and religious-such as schools, religious centers, or the army

(4) it has to be reflected in all the societal channels of communication from advertising or films to TV programs and school textbooks

(5) it requires the creation of supportive, new norms that will be informally enforced via social sanctions

(6) it requires the support of legislation against racism, discrimination, and exploitation in order to enforce new values of coexistence [10].

The International Commission on Education for the Twenty-first Century, under the chairmanship of Jacques Delors of France, in its 1996 report Learning: The Treasure Within, submitted to UNESCO, Paris, felt that education is "a means of bringing about personal development and building relationships among individuals, groups and nations." In the view of the commission, education in the twenty first century is based upon four pillars: learning to know, learning to do, learning to live together, and learning to be [17].

\section{Viewing Others as Having the Same Right to Exist and Live in Peace}

Viewing others as having the same right to exist and livein peace and that they are as deserving of love, respect and kind treatment as we are, is vital in the preservation of interreligious, inter-racial and inter-ethnic relationships. Justice demands that each race or ethnicity be granted a right to develop itself and to take pride in its own identity.

Justice is the bridge that binds people of different backgrounds together and transforms them into one brotherhood, with each member acting as a protector of the other and responsible for each other's well-being. Allah says (interpretation of the meaning):

"We sent aforetime our apostles with Clear Signs and sent down with them the Book and the Balance (of Right and Wrong), that men may stand forth in justice; and We sent down Iron, in which is (material for) mighty war, as well as many benefits for mankind, that Allah may test who it is that will help, Unseen, Him and His apostles: For Allah is Full of Strength, Exalted in Might (and able to enforce His Will)."21

It is understood from this verse that the ultimate objective and aim of Islam is justice. It is also the reason why Allah sent His Messengers (peace and blessings be upon them) along with the scriptures.

\section{Implementation of Core Moral Values}

Core moral values are the "core beliefs and principles that should be manifested in the behaviors of every individual member of family and society'. They are the "moral compass" that guide the members of family and society on how they should perform their day-to-day activities thereby enabling the family or society to live in peace and harmony and to attain al-Falah (success and development). They form the foundation on which a peaceful and harmonious society is built. Here are some of these principles: trustworthiness, honesty, integrity, respect, solidarity, fairness, compassion,

\footnotetext{
${ }^{21}$ Qur'an, 57:25.
} 
loyalty, selflessness, beneficence, maintaining relations with kin, cooperation, and responsibility. The following are some of the Qur'anic verses and Hadith on core moral values:

"Allah commands justice, the doing of good, and liberality to kith and kin, and He forbids all shameful deeds, and injustice and rebellion: He instructs you, that ye may receive admonition.",22

"And render to the kindred their due rights, as (also) to those in want, and to the wayfarer: But squander not (your wealth) in the manner of a spendthrift."23

"Serve Allah and join not any partners with Him; and do good- to parents, kinsfolk, orphans, those in need, neighbours who are near, neighbours who are strangers, the companion by your side, the wayfarer (ye meet), and what your right hands possess: For Allah loveth not the arrogant, the vainglorious." 24

"O ye who believe! Violate not the sanctity of the symbols of Allah, nor of the sacred month, nor of the animals brought for sacrifice, nor the garlands that mark out such animals, nor the people resorting to the sacred house, seeking of the bounty and good pleasure of their Lord. But when ye are clear of the sacred precincts and of pilgrim garb, ye may hunt and let not the hatred of some people in (once) shutting you out of the Sacred Mosque lead you to transgression (and hostility on your part). Help ye one another in righteousness and piety, but help ye not one another in sin and rancour: fear Allah. for Allah is strict in punishment." 25

"None of you [truly] believes until he loves for his brother that which he loves for himself" [18].

\section{E. Communication Skills}

Communicate is one of the ways by which human beings relate to each other. There are two types of communication, namely verbal and nonverbal. The former is communication through words. The latter is communication through symbols, gestures, facial expressions, eye gaze, body language, etc.

Following the Sunnah of the Prophet (peace and blessings be upon him) when communicating with people of various races and ethnicities, verbally or nonverbally, is another step to peaceful coexistence. The Prophet (peace and blessings be upon him) used to communicate with people in a concise, clear, gentle, respectful and friendly manner. As a result, he was successful in his $d a$ ' wah (invitation to Islam). Allah says (interpretation of the meaning):

"It is part of the Mercy of Allah that thou dost deal gently with them Wert thou severe or harsh-hearted, they would have broken away from about thee: so pass over (Their faults), and ask for (Allah's) forgiveness for them; and consult them in affairs (of moment). Then, when thou hast taken a decision put thy trust in Allah. For Allah loves those who put their trust (in Him)."26

Additionally, the Prophet (peace and blessings be upon him) used to greet people with a smile and he said: "Your smiling in the face of your brother is charity" [19]. He also used to shake hands of his companions and he is reported to have said: "No two Muslims meet each other and shake hands but that Allah forgives them before they part" [9]. Salam and shaking of hand remove any past ill feelings that could be present and creates love between Muslims. It is one of the methods of dispute resolution.

In the following verse Muslims are instructed to settle disputes between them and other nations with the aim of forging unity and establishing peace:

"The Believers are but a single Brotherhood: So, make peace and reconciliation between your two (contending) brothers; and fear Allah, that ye may receive Mercy."27

The Qur'an uses the following concepts to describe the Islamic ethics of interpersonal communication or the principles, rules and regulations of communication among human beings, regardless of whether that communication takes place in face-to-face settings or through platforms such as social media: Qawlan sadida (Qur'an, 33:70), Qawlan ma'rufa (Qur'an, 4:9 \& 33:32), Qawlan karima (Qur'an, 17:23), Qawlan maysura (Qur'an, 17:28), Qawlan baligha (Qur'an, 4:63) and Qawlan layyina (Qur'an, 20:44). Hence, the speech or communication that Allah appreciates is that which consists of noble words (Qawlan karima), good words (Qawlan ma 'rufa); true, straight and honest (Qawlan sadida); easy, appropriate, concise and precise (Qawlan maysura); gentle and mild (Qawlan layyina); and far reaching, easy to understand, fluent and clear (Qawlan baligha).

From the foregoing, we can conclude that the Islamic principles, rules and regulations of communication among human beings are clarity, politeness, gentleness, respectfulness, coherence, friendliness, honesty, and comprehensibility, among others. Therefore, one should articulate words clearly, slowly, precisely, gently, appropriately, etc. One "must always be careful, think about and reflect on what to be spoken" [20]. The words used in communication with others must be in accordance with core Islamic values and teachings. They must be free from mockery, deception, and any prejudices based on colour, language, race, culture, religion, or nationality. Good communication is an integral part of conflict resolution and key to creation of peace and harmony. Allah says (interpretation of the meaning):

"Nor can goodness and evil be equal. Repel (evil) with what is better: Then will he between whom and there was hatred become as it were thy friend and intimate!"28

In the following verse, Muslims are ordered to be gentle, wise, cultured and patient when introducing and inviting others to Islam or when commanding the good and forbidding the evil:

"Invite (all) to the Way of thy Lord with wisdom and beautiful preaching; and argue with them in ways that are best and most gracious: for thy Lord knowed best, who have strayed from His Path, and who receive guidance." 29

Fir'aun (Pharaoh) is described in the Qur'an as a tyrant, an oppressor and a man who spread corruption of severe magnitude and transgressed all boundaries (Qur'an, 2:49; 7:141; and 89:10-12) yet, when Allah sent His two Prophets, Musa and Harun (peace and blessings be upon them), to

\footnotetext{
${ }^{26}$ Qur'an, 3:159.

${ }^{27}$ Qur'an, 49:10.

${ }^{28}$ Qur'an, 41:34.

${ }^{29}$ Qur'an, 16:125.
} 
convey His Message to him, He ordered them to speak gently to him:

"Go, both of you, to Pharaoh, for he has indeed transgressed all bounds; But speak to him mildly; perchance he may take warning or fear (Allah)." ${ }^{30}$

From this it follows that gentleness is required in all situations and at all times. 'Aishah (may Allah be pleased with her) reported: The Prophet (peace and blessings be upon him) said, "Verily, gentleness is not found in anything but that it beautifies it, and it is not removed from anything but that it disgraces it" [7].

\section{CAtegorization of Peaceful Coexistence}

This section aims to describe the following categories of peaceful coexistence:

a) Peaceful coexistence in marriage;

b) Peaceful coexistence of mankind;

c) Peaceful coexistence of the members of the Muslim ummah;

d) Peaceful coexistence of mankind and the environment.

\section{A. Peaceful Coexistence in Marriage}

Marriage is the foundation of family life. This means, it is through marriage a family is established. One of the responsibilities of husband and wife is to establish a communion of love, care and mercy into which children are born and raised. Allah says (interpretation of the meaning):

"If ye fear that ye shall not be able to deal justly with the orphans, marry women of your choice, Two or three or four; but if ye fear that ye shall not be able to deal justly (with them), then only one, or (a captive) that your right hands possess, that will be more suitable, to prevent you from doing injustice." 31

"And among His Signs is this, that He created for you mates from among yourselves, that ye may dwell in tranquility with them, and $\mathrm{He}$ has put love and mercy between your (hearts): verily in that are Signs for those who reflect." 32

"Ye who believe! Ye are forbidden to inherit women against their will. Nor should ye treat them with harshness, that ye may Take away part of the dower ye have given them, except where they have been guilty of open lewdness; on the contrary live with them on a footing of kindness and equity. If ye take a dislike to them it may be that ye dislike a thing, and Allah brings about through it a great deal of good." 33

The history of marriage and family begins with Adam and Hawa (Eve), the first humans on the earth. Allah says (interpretation of the meaning):

"O mankind! reverence your Guardian-Lord, who created you from a single person, created, of like nature, His mate, and from them twain scattered (like seeds) countless men and women; reverence Allah, through whom ye demand your mutual (rights), and (reverence) the wombs (That bore you): for Allah ever watches over you." 34

\footnotetext{
${ }^{30}$ Qur'an, 20:43-44.

${ }^{31}$ Qur'an, 4:3.

${ }^{32}$ Qur'an, 30:21

${ }^{33}$ Qur'an, 4:19.

${ }^{34}$ Qur'an, 4:1.
}

"Mankind was one single nation, and Allah sent Messengers with glad tidings and warnings; and with them He sent the Book in truth, to judge between people in matters wherein they differed; but the People of the Book, after the clear Signs came to them, did not differ among themselves, except through selfish contumacy. Allah by His Grace Guided the believers to the Truth, concerning that wherein they differed. For Allah guided whom He will to a path that is straight." 35

It is understood from the above verses that: first, men and women are partners in the worldly life; second, love and mercy between the couple (husband and wife) is needed for peaceful coexistence in marriage; third, all humans are members of one family of Adam and Hawa (Eve); fourth, it is from the family of Adam and Hawa that other families and descendants were derived, then communities and then societies and nations. To put it in simple terms, diversity was created from single parenthood and marriage was one of the factors that led to the breakdown of mankind. Fifth, it is from unity and solidarity that the various ethnic traditions and cultures were born. Here it is worth noting that the concept ummatan wahidah (one nation) refers to unity in the context of religious life and racial and harmony, and also unity in the context of ethnic coexistence.

\section{B. Peaceful Coexistence of Mankind}

Islam teaches that mankind was created from a single person, namely Adam, and that Adam was made from the earth, which means that all human beings were made from the earth too, therefore, they are all equal and honorable (they deserve to be respected). Allah says (interpretation of the meaning):

"From the (earth) did We create you, and into it shall We return you, and from it shall We bring you out once again."36

"O mankind! reverence your Guardian-Lord, who created you from a single person, created, of like nature, His mate, and from them twain scattered (like seeds) countless men and women; reverence Allah, through whom ye demand your mutual (rights), and (reverence) the wombs (That bore you): for Allah ever watches over you." 37

From the above verses it is understood that peaceful coexistence of mankind is based, among others, on fairness and good treatment to all human beings without discrimination on the basis of religion, color, race, sex or nationality.

"We have honored the sons of Adam; provided them with transport on land and sea; given them for sustenance things good and pure; and conferred on them special favors, above a great part of our creation." 38

In this verse Allah has made no distinction between Muslims and non-Muslims in matters of respect of human rights and administration of justice.

Narrated Ibn 'Umar that the Messenger of Allah (peace and blessings be upon him) gave a Khutbah (sermon) to the people on the day of the conquest of Makkah, and he said: "O you people! Verily Allah has removed the slogans of

\footnotetext{
${ }^{35}$ Qur'an, 2:213.

${ }^{36}$ Qur'an, 20:55.

${ }^{37}$ Qur'an, 4:1.

${ }^{38}$ Qur'an, 17:70.
} 
Jahiliyyah (the time of ignorance) from you, and its reverence of its forefathers. So, now there are two types of men: A man who is righteous, has Taqwa (piety/fear) and honourable before Allah, and a wicked man, who is miserable and insignificant to Allah. People are children of Adam and Allah created Adam from the dust. Allah said: O you people! We have created you from a male and a female, and made you into nations and tribes, that you may know one another. Verily, the most honourable of you with Allah is the one who has most Taqwa. Verily, Allah is All-Knowing, AllAware (49:13)" [19].

\section{Peaceful Coexistence of the Members of the Muslim Ummah}

It is impossible to comprehend any concept without knowing its literal and technical definitions. Technically, the term ummah refers to a group of people who lived at a particular time for whom a Messenger or Prophet was sent regardless of whether they believed or disbelieved. Allah says (interpretation of the meaning):

"For We assuredly sent amongst every People a messenger, (with the Command), "Serve Allah, and eschew Evil": of the People were some whom Allah guided, and some on whom error became inevitably (established). So, travel through the earth, and see what was the end of those who denied (the Truth)." 39

Muslim ummah is a community distinguished by the following:

1) Non-territoriality and boundlessness.

2) A common faith, i.e. shahadah or the testimony of Allah's Oneness and the Messengership of Muhammad (peace and blessings be upon him).

3) A single brotherhood.

4) A common goal.

5) Duty consciousness and exemplariness.

6) Noble character.

7) Wasatiyyah.

\section{1) Non-territoriality and Boundlessness}

The Muslim ummah is a small religious group of diverse cultures within a larger human community. One of its distinctive characteristics is universality and timelessness or non-territoriality. This means, it is a community which does not function within a particular geographic area. It transcends geographical, cultural, tribal, and ethnic boundaries. It extends through all times and places.

Muslims, wherever they are, constitute an integral part of the larger Muslim community despite their cultural diversity. The teachings of the Prophets and Messengers (peace and blessings be upon them) before the advent of Islam were limited to their respective nations and applied for a limited period of time. The teachings of the Prophet Muhammad (peace and blessings be upon him), however, are addressed to all nations and they are for all time.

2) A Common Faith (i.e., shahadah - the testimony of Allah's Oneness and the Messengership of Muhammad (peace and blessings be upon him)
The testimony of Allah's Oneness and the Messengership of Muhammad (peace and blessings be upon him) is the first of the five pillars of Islam. From this testimony other facets of faith, namely belief in the existence of Angels, belief in the books of Allah, belief in Allah's Messengers and that Muhammad is the last of them, belief in the Day of Judgment and belief in the Qadha' and Qadr (Doom \& Divine Decree) spring.

The testimony of the oneness of Allah means, among others, conviction, and acknowledgement that no deity is worthy of one's worship, obedience, ultimate loyalty, love, sacrifice, subservience, praise, hope, and fear, other than Allah:

"Say: He is Allah, the One and Only; Allah, the Eternal, Absolute; He begetteth not, nor is He begotten; and there is none like unto Him." 40

"And your Allah is One Allah. There is no god but He, Most Gracious, Most Merciful.,"41

"Verily, I am Allah. There is no god but I: So, serve thou $\mathrm{Me}$ (only), and establish regular prayer for celebrating My praise" (Qur'an, 20:14).

The testimony of Allah's Oneness and the Messengership of Muhammad (peace and blessings be upon him) is the foundation on which Muslim unity is build. Historically, human beings were one nation, but they became divided because of ideological differences among them:

"Mankind was one single nation, and Allah sent Messengers with glad tidings and warnings; and with them He sent the Book in truth, to judge between people in matters wherein they differed; but the People of the Book, after the clear Signs came to them, did not differ among themselves, except through selfish contumacy. Allah by His Grace Guided the believers to the Truth, concerning that wherein they differed. For Allah guided whom He will to a path that is straight." 42

\section{3) A Single Brotherhood}

The believers are one single brotherhood. Hence, they are urged to work together to promote Muslim unity. Being one single brotherhood means, each one of them serves as each other's protector, helper, and guide. They are equal, dutiful to one another and have a peaceful relationship with each other. Part of their duties is to avoid whatever may cause division within the ummah such as conflicts. There should be no backbiting, enmity, envy, and jealousy among them. Allah says (interpretation of the meaning):

"O ye who believe! Let not some men among you laugh at others: It may be that the (latter) are better than the (former): Nor let some women laugh at others: It may be that the (latter are better than the (former): Nor defame nor be sarcastic to each other, nor call each other by (offensive) nicknames: Illseeming is a name connoting wickedness, (to be used of one) after he has believed: And those who do not desist are (indeed) doing wrong." 43

"The Believers are but a single Brotherhood: So, make peace and reconciliation between your two (contending) brothers; and fear Allah, that ye may receive Mercy."44

\footnotetext{
${ }^{39}$ Qur'an, 16:36.

${ }^{40}$ Qur'an, 112: 1-4.

${ }^{41}$ Qur'an, 2:163.
}

${ }^{42}$ Qur'an, 2:213.
${ }^{43}$ Qur'an, 49:11.
${ }^{44}$ Qur'an, 49:10. 
Ünal describes backbiting as "a shameful weapon and most commonly used by people of enmity, envy, and obstinacy". He believes that "no self-respecting, honorable human being would ever demean themselves by resorting to such a vile weapon" [21].

Islamic brotherhood is characterized by affection, among others. Al-Nu'man ibn Bashir (may Allah be pleased with him) reported: The Messenger of Allah (peace and blessings be upon him) said: "The parable of the believers in their affection, mercy, and compassion for each other is that of a body. When any limb aches, the whole body reacts with sleeplessness and fever" [6], [7]. Hence, any aggression against any member of the Muslim ummah is an aggression against all members.

All Muslims should feel a sense of belonging to this single ummah (community) whose membership is open to those who acknowledge Allah's Oneness and the Messengership of Muhammad (peace and blessings be upon him). They should peacefully coexist without any discrimination or restriction. Each member should feel secure. 'Abdullah ibn 'Umar (may Allah be pleased with him) reported: The Messenger of Allah (peace and blessings be upon him) said: "A Muslim is a brother to another Muslim. He does not wrong him, nor surrender him. Whoever fulfils the needs of his brother, Allah will fulfil his needs. Whoever relieves a Muslim from distress, Allah will relieve him from distress on the Day of Resurrection. Whoever covers the faults of a Muslim, Allah will cover his faults on the Day of Resurrection" [6], [7].

A sense of belonging is crucial to improvement and development of the Muslim ummah while estrangement or social alienation is detrimental to its development and cohesion. Hence, it is forbidden for a Muslim to have estranged relations with the other Muslim beyond three days for no justified reason.

Abu Ayyub al-Ansari (may Allah be pleased with him) reported Allah's Messenger (peace and blessings be upon him) as saying: "It is not permissible for a Muslim to have estranged relations with his brother beyond three nights, the one turning one way and the other turning the other way when they meet; the better of the two is one who is the first to give salam (a greeting)" [7]. Commenting on this Hadith, Zubair and Azhar wrote, "This hadith highlights the merit of Salam (salutation), a specific and easy way for resuming the relation, because Salam paves the way for talk and reconciliation" [22].

The act of smiling is another means to peace and reconciliation. Not only that it makes a person more approachable and easier to talk to, but it also signifies that he or she is interested in socializing with others. In other words, it oils the gears of social interactions. According to the following Hadith, smiling is voluntary charity:

Abu Dharr (may Allah be pleased with him) narrated that the Messenger of Allah (peace and blessings be upon him) said: "You're smiling in the face of your brother is charity, commanding good and forbidding evil is charity, your giving directions to a man lost in the land is charity for you. You're seeing for a man with bad sight is a charity for you, your removal of a rock, a thorn or a bone from the road is charity

\footnotetext{
${ }^{45}$ Qur'an, 59:9.
}

for you. You're pouring what remains from your bucket into the bucket of your brother is charity for you" [19].

The Prophet (peace and blessings be upon him) was congenial and cheerful; his presence provided a warm and friendly environment. Jarir ibn 'Abdullah (may Allah be pleased with him) said: “Allah's Messenger (peace and blessings be upon him) never refused me permission to see him since I embraced Islam and never looked at me but with a smile" [7].

Abu Hurayrah (Allah be pleased with him) narrated that the Messenger of Allah (peace and blessings be upon him) said: "You (people) cannot satisfy people with your wealth but satisfy them with your cheerful faces and good morals" [23]. According to Voltaire "Smile melts ice, installs confidence and heals wounds; it's the key to sincere human relations" [24].

Among the remarkable achievements of the Prophet (peace and blessings be upon him) were the institutionalization of al-Mu'akhat or brotherhood between al-Muhajirun (the emigrants from Makkah) and al-Ansar (the helpers or the local inhabitants of Madinah) and creation of mithaq al-Madinah (the constitution of Madinah or Madinah Charter). The latter is comprised of two parts. Part one addresses "mutual relations among Muslims" while part two describes the "rules to regulate inter-communal affairs between Muslims and Jews" [25]. Both the brotherhood between al-Muhajirun and al-Ansar, and the constitution of Madinah formed the basis of a harmonious, affectionate, and cohesive society. Hence, it can be concluded that peaceful coexistence requires installation of love and affection in individuals' hearts for each other, and recognition of the rights and responsibilities of each group in the society. Allah describes al-Ansari's unconditional love and affection for alMuhajirin and their sincere generosity towards them as follows:

"But those who before them, had homes (in Medina) and had adopted the Faith, show their affection to such as came to them for refuge, and entertain no desire in their hearts for things given to the (latter), but give them preference over themselves, even though poverty was their (own lot). And those saved from the covetousness of their own souls, they are the ones that achieve prosperity." 45

To sum up, the Madinan society was unique in the sense that it was based on social justice and Islamic or human values such as respect for others, openness, empathy and love towards other human beings, acceptance, sincerity, cooperation, brotherhood, non-violence, friendship, fairness, loyalty, and solidarity. It was and will continue to be described as the best example of a peaceful plural society.

\section{4) A Common Goal}

The ultimate goal of Muslims is to attain Allah's pleasure and draw near to Him by adhering to His commands. He says (interpretation of the meaning):

"And they have been commanded no more than this: To worship Allah, offering Him sincere devotion, being true (in faith); to establish regular prayer; and to practise regular charity; and that is the Religion Right and Straight." ${ }^{46}$

"Those to whom We have given the Book rejoice at what hath been revealed unto thee: but there are among the clans 
those who reject a part thereof. Say: "I am commanded to worship Allah, and not to join partners with Him. Unto Him do I call, and unto Him is my return."',47

For a Muslim, the pleasure of Allah is above and before all else. This means, it is more precious than anything else:

"Allah hath promised to Believers, men and women, gardens under which rivers flow, to dwell therein, and beautiful mansions in gardens of everlasting bliss. But the greatest bliss is the good pleasure of Allah. that is the supreme felicity." $" 48$

In the following verse, Allah praised the Prophet (peace and blessings be upon him) and his companions (may Allah be pleased with them) for their diligence in seeking His pleasure:

"Muhammad is the apostle of Allah. and those who are with him are strong against Unbelievers, (but) compassionate amongst each other. Thou wilt see them bow and prostrate themselves (in prayer), seeking Grace from Allah and (His) Good Pleasure...."49

It is understood from this verse that being compassionate to others (Muslims and non-Muslims, friends, and enemies and even the animals) is amongst the traits that help the believer in attaining the pleasure of Allah.

Narrated 'Abdullah ibn 'Amr ibn al-'As (may Allah be pleased with him): The Prophet (peace and blessings be upon him) said: "The Compassionate One has mercy on those who are merciful. If you show mercy to those who are on the earth, He Who is in the heaven will show mercy to you" [26].

Other traits that lead to the attainment of the pleasure of Allah include giving zakat and sadaqah (charity) to help the needy persons, honoring one's parents, remembrance of Allah, seeking and granting forgiveness, appreciation, and patience.

It is worth noting that seeking the pleasure of Allah is the sole objective for which we had been created. Allah says: "And I (Allah) created not the jinns and humans except they should worship Me (Alone)." 50 This is done by bartering one's life and belongings with Allah in exchange of Paradise in the Hereafter Life. Allah says (interpretation of the meaning):

"Allah hath purchased of the believers their persons and their goods; for theirs (in return) is the garden (of Paradise): they fight in His cause and slay and are slain: a promise binding on Him in truth, through the Law, the Gospel, and the Qur'an: and who is more faithful to his covenant than Allah. then rejoice in the bargain which ye have concluded: that is the achievement supreme." $" 51$

"And the likeness of those who spend their substance, seeking to please Allah and to strengthen their souls, is as a garden, high and fertile: heavy rain falls on it but makes it yield a double increase of harvest, and if it receives not Heavy rain, light moisture sufficeth it. Allah seeth well whatever ye do." 52

\section{5) Duty Consciousness and Exemplariness}

The Muslim ummah serves as a shining example to other nations. It is described as khayr ummah (The Best Community); that is, a community that embodies the best moral values that include respect for elders, the rights of others and the law, honesty, trustworthiness, caring, fairness, sense of responsibility, cooperation on good deeds and piety, accountability, fulfillment of promises, diligence, reliability, integrity, sharing knowledge, ideas and skills with others, absence of favoritism, prejudice, hatred, and racism. Members of this community live their lives by such values as guiding principles. Allah says (interpretation of the meaning):

"Ye are the best of peoples (Khayr ummah), evolved for mankind, enjoining what is right, forbidding what is wrong, and believing in Allah. If only the People of the Book had faith, it was best for them: among them are some who have faith, but most of them are perverted transgressors."

Allah commanded salat, zakat, sawm (fasting) and hajj as pillars of Islam with the aim to purify the hearts of human beings as is evident in the verses below:

"Recite what is sent of the Book by inspiration to thee and establish regular Prayer: for Prayer restrains from shameful and unjust deeds; and remembrance of Allah is the greatest (thing in life) without doubt. And Allah knows the (deeds) that ye do." 54

"Of their goods, take alms, that so thou mightiest purify and sanctify them; and pray on their behalf. Verily thy prayers are a source of security for them: And Allah is One Who heareth and knowed." 55

"O ye who believe! Fasting is prescribed to you as it was prescribed to those before you, that ye may (learn) selfrestraint." $" 56$

"For Hajj are the months well known. If anyone undertakes that duty therein, let there be no obscenity, nor wickedness, nor wrangling in the Hajj. And whatever good ye do, (be sure) Allah knowed it. And take a provision (With you) for the journey, but the best of provisions is right conduct. So, fear Me, o ye that are wise." 57

Here it is understood that salat, zakat, sawm and hajj are steppingstones to righteousness. Salat is an act of reverence, gratitude, and total submission to Allah. It prevents a person from obscenity and shameful activities, and it is also a means to punctuality, cleanliness, and purity of the heart; it purifies the heart from spiritual diseases such as arrogance and makes a person humble; zakat is an act of kindness, sympathy and benevolence. It cleanses the self of greed, selfishness and envy; sawm abstains from wicked and obscene things and adorns the heart with patience, generosity and many other spiritual virtues; and hajj is a symbol of Muslim unity, brotherhood, cooperation, affection and humility. It adorns the heart with patience and abstains from immoral acts and disputes.

It is worth noting that iman (belief in Allah's Existence) and 'amal al-Salih (righteous deeds) are always mentioned

\footnotetext{
${ }^{53}$ Qur'an, 3:110.

${ }^{54}$ Qur'an, 29:45.

${ }^{55}$ Qur'an, 9:103.

${ }^{56}$ Qur'an, 2:183.

${ }^{57}$ Qur'an, 2:197.
} 
together in the Qur' an because they are the guiding principles of morality. Iman entails muraqabah (watchfulness of Allah or awareness of one's accountability towards Allah) and taqwa (inner consciousness of one's duties towards Allah). Muraqabah is our spiritual sense. It is to observe Allah in everything we do; putting Him at the centre of our activities; sensing or keeping in mind that He is watching us wherever we are. Allah says (interpretation of the meaning):

"Seest thou not that Allah doth know (all) that is in the heavens and on earth? There is not a secret consultation between three, but He makes the fourth among them, nor between five but He makes the sixth, nor between fewer nor more, but $\mathrm{He}$ is in their midst, wheresoever they be: In the end will He tell them the truth of their conduct, on the Day of Judgment. For Allah has full knowledge of all things."

"He it is Who created the heavens and the earth in Six Days and is moreover firmly established on the Throne (of Authority). He knows what enters within the earth and what comes forth out of it, what comes down from heaven and what mounts up to it. And He is with you wheresoever ye may be. And Allah sees well all that ye do." 59

Muslim community is a group of people who perform the following duties: first, they manifest Allah's Authority, that is, al-Din (religion) or al-Shari' 'ah, on the earth; second, they follow in "the footsteps of earlier Messengers from among the descendants of Noah and Abraham;" third, they take care of the essential needs of each person of the entire ummah, and fourth, they stand forth in justice. Allah says (interpretation of the meaning):

"The same religion has $\mathrm{He}$ established for you as that which He enjoined on Noah - the which We have sent by inspiration to thee - and that which We enjoined on Abraham, Moses, and Jesus: Namely, that ye should remain steadfast in religion, and make no divisions therein: to those who worship other things than Allah, hard is the (way) to which thou callest them. Allah chooses to Himself those whom $\mathrm{He}$ pleases, and guides to Himself those who turn (to Him). $"{ }^{\circ 0}$

"And We sent Noah and Abraham, and established in their line Prophethood and Revelation, and some of them were on right guidance. But many of them became rebellious transgressors." 61

"O ye who believe! stand out firmly for justice, as witnesses to Allah, even as against yourselves, or your parents, or your kin, and whether it be (against) rich or poor: for Allah can best protect both. Follow not the lusts (of your hearts), lest ye swerve, and if ye distort (justice) or decline to do justice, verily Allah is well- acquainted with all that ye do" 62

\section{6) Wasatiyyah}

The Arabic term wasatiyyah is derived from wasat which denotes the meaning of superiority, justice, purity, nobility, elevated status [27] and "the best and most excellent." The Quraysh are described as awsat al- 'Arab nasaban wa daran, meaning they are "the best of the Arabs in lineage and abode," and the Prophet Muhammad (peace and blessings be upon him) is described as wasatan fi qawmihi, meaning "the

\footnotetext{
${ }^{58}$ Qur'an, 58:7.

${ }^{59}$ Qur'an, 57:4

${ }^{60}$ Qur'an, 42:13.

${ }^{61}$ Qur'an, 57:26.
}

best of his people and noblest in lineage". Al-Salat al-Wusta means "the best prayer" and that is 'Asr prayer, as is narrated in the authentic books and elsewhere" [28].

Allah describes the Muslim ummah as ummatan wasatan. He says (interpretation of the meaning):

"Thus, have We made of you an ummatan wasatan (a justly balanced nation), that ye might be witnesses over the nations, and the Messenger a witness over yourselves...."63

Ibn Kathir said in his commentary on this verse: Thus, ummatan wasatan is "the just," "the best (in goodness or quality)," "the top choice," "the finest," and "the most honorable" ummah (nation) [28].

Shaykh Ibn 'Uthaymeen (may Allah have mercy on him) said: What we learn from this verse (Qur'an, 2:143) is "the superiority of this ummah (i.e., the Muslim nation) over other nations" [29].

Narrated Abu Sa'id (may Allah be pleased with him): Allah's Messenger (peace and blessings be upon him) said: "Noah and his nation will come (on the Day of Resurrection and Allah will ask (Noah), 'Did you convey (the Message)?' He will reply, 'Yes, O my Lord!' Then Allah will ask Noah's nation, 'Did Noah convey My Message to you?' They will reply, 'No, no Prophet came to us.' Then Allah will ask Noah, 'Who will stand a witness for you?' He will reply, 'Muhammad and his followers (will stand witness for me).' So, I and my followers will stand as witnesses for him (that he conveyed Allah's Message)." That is, (the interpretation) of the Statement of Allah: "Thus we have made you a just and the best nation that you might be witnesses over mankind..."64 [6].

It is crystal clear from the foregone Hadith that ummatan wasatan is the nation "that will bear witness for Prophets and Messengers (peace and blessings be upon them) against their nations on the Day of Judgement that they (the Prophets and Messengers) conveyed the Message to them and the Prophet Muhammad (peace and blessings be upon him) will bear witness over it."

Here follows a question: How will the Muslim ummah bear witness for Prophets and Messengers (peace and blessings be upon them) against their nations when they were not their contemporaries? According to Ibn 'Uthaymeen, they will base their witness on what they heard from Prophet Muhammad (peace and blessings be upon him), whose words are more authentic than what one sees with one's own eyes, that the Prophets and Messengers (peace and blessings be upon them) conveyed Allah's Message to their people) [29].

Al-Baghawi is reported to have narrated in his Tafsir that Al-Kalbi said: Wasatan means "the followers of the wasat religion, one that represents a middle path between exaggeration and negligence, because both are blameworthy in the matter of religion" [29].

Hence, a community of the middle path is the one which is lenient in its human relations, balanced in its beliefs, attitude and worldview, spiritual needs and material needs, acts of worship and rituals, and legislation and thought. It rejects extremism, takes a middle path between individualism and socialism, materialism and spiritualism,

\footnotetext{
${ }^{62}$ Qur'an, 4:135.

${ }^{63}$ Qur'an, 2:143.

${ }^{64}$ Qur'an, 2:143.
} 
exaggeration and negligence, and idealism and realism. Allah says (interpretation of the meaning):

"Those who, when they spend, are not extravagant and not niggardly, but hold a just (balance) between those (extremes)." ${ }^{, 65}$

\section{Peaceful Coexistence of Human Beings with Nature/Environment}

Here are the crucial questions about peaceful coexistence of human beings and environment: What is environment? Why is it important? What is the relationship of humans and the environment? And what are the human environmental responsibilities?

Used interchangeably with 'nature', the term 'environment' has a broad range of definitions, meanings, and interpretations. Literally, it means 'surroundings in which we live' (environs). Technically, it is perceived to be composed of "all, or any, of the [media] the air, water and land; and the medium of air includes the air within buildings and the air within other natural or man-made structures above or below ground" [30], or "all those elements which in their complex inter-relationships form the framework, setting and living conditions for mankind, by their very existence or by virtue of their impact. Humans, like other living creatures, have a relationship with the environment" [30]. From these definitions, it is understood that, first, there are two types of environments, namely natural environment, and artificial environment. The former is composed of air, water, soil, plants, animals, and minerals. Water is a basic element of life. All ancient civilisations were established near water, and this clearly indicates that people cannot live without water [31]. Artificial environment or man-made elements is composed of the cultivated fields and cities. Second, humans and environment are interdependent, this means, each depends on the other for survival. For example, weather and climate change is one of the major factors that allow viruses to cause epidemics. It impacts not only human health but animal and plant health as well. Historically, drought led to the collapse of a number of flourishing civilisations. Humans impact the natural environment in many ways. In fact, "all human activities have effects, including negative and harmful, on the environment" [30]. Pollution and deforestation are some of the human actions that have negative harmful effects on the environment.

According to Islam, the earth is: first, one of Allah's creations and a sign of His existence: "To Allah belongeth the dominion of the heavens and the earth; and Allah hath power over all things. Behold! in the creation of the heavens and the earth, and the alternation of night and day, there are indeed Signs for men of understanding." $" 66$

Second, a place of worship, pure and clean: Abu Sa'id alKhudri (may Allah be pleased with him) reported: The Messenger of Allah (peace and blessings be upon him) said: "The entire earth has been made a place of prayer, except for graveyards and washrooms" [19].

\footnotetext{
${ }^{65}$ Qur'an, 25:67.

${ }^{66}$ Qur'an, 3:189-190.

${ }^{67}$ Qur'an, 55:10.

${ }^{68}$ Qur'an, 6:38.

${ }^{69}$ Qur'an, 2:30.
}

Third, home to diversity of organisms, namely birds, animals, plants and microorganisms, which coexist with humans: "It is He Who has spread out the earth for (His) creatures"67; "There is not an animal (that lives) on the earth, nor a being that fly on its wings, but (forms part of) communities like you. Nothing has we omitted from the Book, and they (all) shall be gathered to their Lord in the end." 68

Like humans, other living creatures use nature to obtain their food and drink, protect themselves and acquire a habitat. Each species depends on each other to survive, and each has a role to play in the ecosystem. For example, producers, that is, plants, absorb carbon dioxide and release oxygen from their leaves which humans and animals need to breathe, they serve as food, medicine and shelter for humans and animals, and they help to clean water, among others; decomposers such as fungi and bacteria "fertilise the soil with humus by decomposing dead animals and plants to enable plants to grow;" and secondary consumers such as dogs, cats, birds, wolves and other carnivores obtain their energy from primary consumers by scavenging. Fourth, entrusted to humans as caretakers and it has been made subservient to them in order to obtain their food and drink, and fulfill the purpose of their existence:

"Behold, thy Lord said to the angels: "I will create a vicegerent on earth." They said: "Wilt Thou place therein one who will make mischief therein and shed blood? whilst we do celebrate Thy praises and glorify Thy holy (name)?" He said: "I know what ye know not." 69

"Do ye not see that Allah has subjected to your (use) all things in the heavens and on earth, and has made his bounties flow to you in exceeding measure, (both) seen and unseen? Yet there are among men those who dispute about Allah, without knowledge and without guidance, and without a Book to enlighten them!",70

Human environmental responsibilities constitute part of their religious responsibilities. These include conservation of the environment. Hence, they are urged to keep the environment clean and to refrain from any action that may harm the balance of the environment or destroy it: "Destroying the environment is encroaching on the rights of future generations" [31]. They should maintain the balance in the exploitation of the natural resources:

"And the Firmament has He raised high, and He has set up the Balance (of Justice), in order that ye may not transgress (due) balance."71

Allah has forbidden the destruction of the environment: "Do no mischief on the earth, after it hath been set in order, but call on Him with fear and longing (in your hearts): for the Mercy of Allah is (always) near to those who do good." 72 


\section{A SUMMARY OF THE ISLAMIC PRINCIPLES OF PeAceful Coexistence}

\section{A. Peaceful Coexistence in Marriage}

1) Selected verses from the Qur'an Regarding This Type of Coexistence

"And among His Signs is this, that He created for you mates from among yourselves, that ye may dwell in tranquility with them, and $\mathrm{He}$ has put love and mercy between your (hearts): verily in that are Signs for those who reflect." 73

"...Help ye one another in righteousness and piety but help ye not one another in sin and rancour: fear Allah. for Allah is strict in punishment." 74

Islamic principles derived from the above verses:

- Mutual love, affection, tolerance, and care.

- Mutual respect to the rights of spouse.

○ Complementarity or mutual help.

B. Peaceful Coexistence of children and Parents, Members of the Family and Neighbours

Selected verse from the Qur'an regarding this type of coexistence:

"Serve Allah and join not any partners with Him; and do good- to parents, kinsfolk, orphans, those in need, neighbours who are near, neighbours who are strangers, the companion by your side, the wayfarer (ye meet), and what your right hands possess: For Allah loveth not the arrogant, the vainglorious." 75

Islamic principles derived from the above verse:

- Mutual love, affection, care and fellow feeling.

- Respect for parents and elderly family members.

- Generosity to the needy/fulfilment of the needs of Ohelpless.

$\circ$ Affection and love for the young ones.

- Fulfilment of one's duties to children, parents, family members and neighbours.

\section{Peaceful Coexistence of Various Ethnic and Racial Groups in Islam}

\section{1) Selected verses from the Qur'an and Hadith} regarding this type of coexistence:

"O ye who believe! Let not some men among you laugh at others: It may be that the (latter) are better than the (former): Nor let some women laugh at others: It may be that the (latter are better than the (former): Nor defame nor be sarcastic to each other, nor call each other by (offensive) nicknames: Illseeming is a name connoting wickedness, (to be used of one) after he has believed: And those who do not desist are (indeed) doing wrong." 76

"But if ye enter houses, salute each other - a greeting of blessing and purity as from Allah...."77

"Nor can goodness and Evil be equal. Repel (Evil) with what is better: Then will he between whom and there was hatred become as it were thy friend and intimate!"78

\footnotetext{
${ }^{73}$ Qur'an, 30:21.

${ }^{74}$ Qur'an, 5:2.

${ }^{75}$ Qur'an, 4:36.

${ }^{76}$ Qur'an, 49:11.

${ }^{77}$ Qur'an, 24:61.

${ }^{78}$ Qur'an, 41:34.
}

"You will not enter Paradise until you believe, and you will not (truly) believe until you love one another. Shall I not tell you of something which, if you do it, you will love one another? Spread the greetings of Salam amongst yourselves" (Narrated by Abu Hurayrah) [7].

Islamic principles derived from the above verses and Hadith:

- Mutual recognition of diversity (racial and ethnic differences) as a natural way of life.

- Mutual love, affection, care, and fellow feeling.

- Equality of opportunity or elimination of barriers and impediments to equal opportunities.

- Fair and impartial administration of justice.

- Nurturing salam (greeting of peace).

- Self-discipline/purification of the heart from sicknesses such as egoism, arrogance, conceit, selfishness, greed, lust, intolerance, anger, lying, cheating, gossiping, and slandering.

○ Repulsion of evil with good to win hearts of evil doers and enemies.

\section{Peaceful Coexistence of Various Religious Groups in Islam}

Selected verses from the Qur'an regarding this type of coexistence:

"If it had been thy Lord's will, they would all have believed, all who are on earth! wilt thou then compel mankind, against their will, to believe!"79

"O mankind! We created you from a single (pair) of a male and a female, and made you into nations and tribes, that ye may know each other (not that ye may despise (each other). Verily the most honoured of you in the sight of Allah is (he who is) the most righteous of you. And Allah has full knowledge and is well acquainted (with all things)."

"O ye who believe! stand out firmly for Allah, as witnesses to fair dealing, and let not the hatred of others to you make you swerve to wrong and depart from justice. Be just: that is next to piety: and fear Allah. For Allah is well-acquainted with all that ye do." 81

"Invite (all) to the Way of thy Lord with wisdom and beautiful preaching; and argue with them in ways that are best and most gracious: for thy Lord knoweth best, who have strayed from His Path, and who receive guidance." 82

"And dispute ye not with the People of the Book, except with means better (than mere disputation), unless it be with those of them who inflict wrong (and injury): but say, "We believe in the revelation which has come down to us and in that which came down to you; Our Allah and your Allah is one; and it is to Him we bow (in Islam).", 83

Islamic principles derived from the above verses:

- Mutual respect to the rights of each group.

- Acknowledgement and respect of religious diversity.

- Respect of each other's differences.

- Equality of opportunity.

- Fair and impartial administration of justice.

\footnotetext{
${ }^{79}$ Qur'an, 10:99.

${ }^{80}$ Qur'an, 49:13.

${ }^{81}$ Qur'an, 5:8.

${ }^{82}$ Qur'an, 16:125.

${ }^{83}$ Qur'an, 29:46.
} 
○ Good treatment to all human beings without discrimination.

- Religious freedom.

○ Toleration of each other's religious beliefs even when they don't match their own.

○ Da'wah to Allah with wisdom (softness, politeness, toleration, etc.), beautiful preaching and best arguments.

\section{E. Peaceful Coexistence of human Beings and Naturel Environment}

1) Selected verses from the Qur'an and Hadith regarding this type of coexistence

"Behold, thy Lord said to the angels: "I will create a vicegerent on earth." They said: "Wilt Thou place therein one who will make mischief therein and shed blood? whilst we do celebrate Thy praises and glorify Thy holy (name)?" He said: "I know what ye know not.", 84

"O Children of Adam! wear your beautiful apparel at every time and place of prayer: eat and drink: But waste not by excess, for Allah loveth not the wasters." 85

"Then let man look at his food, (and how We provide it): For that We pour forth water in abundance, and We split the earth in fragments, and produce therein corn, and Grapes and nutritious plants, and Olives and Dates, and enclosed Gardens, dense with lofty trees, and fruits and fodder, for use and convenience to you and your cattle." 86

"The world is sweet and green, and verily Allah is going to install you as vicegerents in it in order to see how you act" (Narrated by Abu Sa'id al-Khudri) [7].

"There is none amongst the Muslims who plants a tree or sows seeds, and then a bird, or a person or an animal eats from it, but is regarded as a charitable gift" (Narrated by Anas ibn Malik) [6].

Islamic principles derived from the above verses and Hadith:

- Proper management of natural resources for the

benefit of the entire human community.

- Love for environment.

○ Self-monitoring.

- Cultivation of land and planting trees and crops.

\section{CONCLUDING REMARKS}

Differences in colour, ethnicity and religion have led to the human race being divided into various groups, each working independently from other groups. Worse still are racial violence and ethnic conflicts. This paper aimed to highlight the need for peaceful coexistence from the perspective of Islam. It started with an introduction on the description of Islam as the greatest blessing Allah has bestowed upon human beings. Subsequently, the paper described the main objectives of Islam, namely to establish a united, inclusive, integrated and consolidated Muslim community, that is, a community in which people of different races and ethnicities live in mutual tolerance, to purify human souls from the spiritual diseases of the heart, such as hatred, malice and the intention to harm others, build peaceful and harmonious interpersonal relationships and also human relationship with other living beings and the environment, to liberate people from oppression, release them from bondage of their desires and provide them with the means for their happiness, and to provide mankind with light that leads from the darkness to the path of peace and salvation; meaning of peaceful coexistence; the need for peaceful coexistence; the necessary requirements and tools for peaceful coexistence; categorization of peaceful coexistence into peaceful coexistence in marriage, peaceful coexistence of mankind, peaceful coexistence of the members of the Muslim ummah and peaceful coexistence of mankind and the environment; and lastly, the summary of the Islamic principles of peaceful coexistence.

It is clear from the foregoing that: first, Allah did not create diversity as a source of discrimination, racial violence and ethnic conflict, but as a source of strength and success of mankind, and a sign for those know.

Second, peaceful coexistence constitutes part and parcel of the teachings of Islam and therefore, it is one of the defining characteristics of the Muslim ummah (nation). The message of Islam is the message of peace and unity for mankind. Other defining characteristics of the Muslim ummah described in this work are non-territoriality and boundlessness. a common faith, i.e., shahadah or the testimony of Allah's Oneness and the Messengership of Muhammad (peace and blessings be upon him), a single brotherhood, a common goal, duty consciousness and exemplariness, noble character and wasatiyyah.

Based on the foregone description, wasatiyyah is freedom from transgression, excessiveness, and injustice. Hence, the Muslim ummah is a community that is committed towards truth, equality, and justice. It is justly balanced in its thoughts, beliefs, and actions. It follows a middle path in the pursuit of spiritual, intellectual, and material development. Not only that Muslims are required to live in peace and harmony with each other, but they are also required to live alongside people of other religions in peace and harmony.

Third, the Islamic principles for peaceful coexistence are mutual love, affection, tolerance and care, fellow-feeling. generosity to the needy and the helpless, affection and love for the young ones. equality of opportunity, fair and impartial administration of justice. greeting of peace, selfdiscipline/purification of the heart from diseases such as egoism, arrogance, conceit, selfishness, greed, lust, intolerance, anger, lying, cheating, gossiping and slandering, mutual respect to the rights of each group, acknowledgement and respect of religious diversity, respect of each other's differences, fair and impartial administration of justice, good treatment to all human beings without discrimination, religious freedom, repulsion of evil with good to win hearts of evil doers and enemies, da'wah to Allah with wisdom (softness, politeness, toleration, etc.), beautiful preaching and best arguments, proper management of natural resources for the benefit of the entire human community, love for environment, self-monitoring, etc.

Fourth, nurturing love, respect, care and salam (the greeting of peace) is vital for peaceful coexistence. 'Abdullah bin 'Amr (may Allah be pleased with him) narrated that: A

\footnotetext{
${ }^{84}$ Qur'an, 2:30.

${ }^{85}$ Qur'an, 7:31.
}

${ }^{86}$ Qur'an, 80:24-32. 
man asked the Prophet (peace and blessings be upon him), "What Islamic traits are the best?" The Prophet said, "Feed the people, and greet those whom you know and those whom you do not know" [6].

Last but not least, chapter 49 verse 13 of the Qur'an indicates that the reason for creating mankind in different tribes and nations is "to know each other" and "treat each with good behavior" such as respect and kindness, rather than cultural assimilation or absorption of the cultures of the minority into the dominant culture of a society. The Islamic concept for "knowing each other" or "knowledge of one another" is ta 'aruf. It is the first step to peaceful coexistence, and it means to obtain the necessary information and knowledge about those who are different from us. Prejudice or the negative preconception toward those who are different from us is one of the factors that prevent peaceful coexistence. According to Encyclopedia.com prejudice means "prejudgment" and it develops when a person "has formed an attitude toward a particular social group of people before having enough information on which to form a knowledgeable opinion".

\section{REFERENCES}

[1] https://www.newmuslimguide.com/en/preliminaries/209. (Accessed on June 27, 2021.)

[2] American Psychological Association, "APA Dictionary of Psychology", 2020.

[3] M. Fabrega, "six ways to achieve inner peace". https://daringtolivefully.com/achieve-inner-peace. (Accessed on August 2, 2021.)

[4] Z. Keskin, "Inner Peace in Islam". Australian Journal of Islamic Studies 1: 23-38, 2016.

[5] S. Al-Nasa'i, "Sunan al-Nasa'I," New Delhi: Kitab Bhavan, 2008.

[6] M. Al-Bukhari, the translation of the meaning of sahih al bukhari, translated by Muhammad Mushin Kan. 1997.

[7] Al-Hajjaj, M. (n.d). Sahih Muslim.

[8] W. M. Watt, "Islam and the Integration of Society," London: Routledge and Kegan Paul Ltd, 1961.

[9] L. Lipson, (1964). "Peaceful Coexistence," Law and Contemporary Problems 29(4): 871-881, 1964.

[10] D. Bar-Tal, "Coexistence Education". Encyclopedia of Peace Education, Teachers College, Columbia University, 2008.

[11] L. Kriesberg, "Coexistence and the Reconciliation of Communal Conflicts." The Handbook of Interethnic Coexistence. Eugene Weiner (ed.). New York: Continuum, 1998.

[12] N. Khaminwa, "Coexistence". 2003

[13] The Council for Global Education. "Coexistence education: Quotations on coexistence," (1998-2021). http://www.globaleducation.org/quotations.htm. (Accessed on August 2, 2021.)

[14] K. J. Oldster, "Dead toad scrolls," 2016.

[15] L. A. Russell-Chapin, "How do we learn to appreciate each other's differences?” 2017. https://www.psychologytoday.com/us/blog/brainwaves/201702/how-do-we-learn-appreciate-each-others-differences. (Accessed on June 26, 2021.)

[16] Kingdom of Bahrain Declaration - King Hamad Global Center for Peaceful Coexistence, "Faith Illuminates our Path to Peace." 2017. https://kinghamadglobalcentre.com/declaration/. (Accessed on August 21, 2021.)

[17] J. Delors, "Learning: The treasure within," UNESCO, 1996.

[18] Z. Al-Nawawi, "The forty hadith of al-Imam an-Nawawi: Text with explanatory notes," Jeddah: Abul-Qasim publishing house, 1999.

[19] M. I. Al-Tirmidhi, "Jami'al-Tirmidhi," Riyadh: Darussalam Publications, 2007.

[20] M. I. Romdiyah, "Islamic Guidance and Counselling in Developing Skills Youth Communication in The Digital Era". Advances in Social Science, Education and Humanities Research, volume 274. 1st International Conference on Creativity, Innovation, Technology in Education (IC-CITE 2018).

[21] Ünal, "The Qur'an with Annotated Interpretation in Modern English," New Jersey: Tughra Books, 2008.
[22] H. M. Zubair and H. H. Azhar, (January 2014). "Islamic Sharia Teachings and Practices for Preventing Bullying," American International Journal of Contemporary Research 4(1), 2014.

[23] H. Al-'Asqalani, "Bulugh al-maram min adillat al-ahkam," Jakarta: Dar al-Kutub al-Islamiyah, 2002.

[24] https://unquote.li/en/quotes/voltaire/smile-melts-ice-installsconfidence-and-heals-wounds-it-s-the-key-of-sincere-humanrelations-7nvyl7n3xp, (Accessed on June 6, 2021.)

[25] Khan, "The Constitution of Medina". 2015 https://www.researchgate.net/publication/228245045_The_Medina_C onstitution. (Accessed on July 5, 2021.)

[26] D. S. Al-Sijistani, "Sunan Abi Dawud," New Delhi: Kitab Bhavan, 1990.

[27] A. Al-Sharbini, “Al-Qașd Wa Al-Wasațiyyah fi dhaw' al-Sunnah alNabawiyyah," Riyadh: Maktabat Al-Rushd, 2010.

[28] U. Ibn Kathir, "Tafsir Ibn Kathir." 1. Riyadh: Darussalam Publications, 2000.

[29] Islam Question \& Answer.

[30] M. L. Larsson, "Legal Definitions of the Environment and of Environmental Damage”, 2019. Stockholm Institute for Scandianvian Law 1957-2009. https://www.scandinavianlaw.se/pdf/38-7.pdf. (Accessed on July 30, 2021.)

[31] M. A. Salem, N. Hasnan and N. H. Osman, "Some Islamic views on environmental responsibility," dalam IPCBEE, 48, 2012. 